\title{
HistoriAR: Experience Indonesian history through interactive game and augmented reality
}

\author{
Shintia Trista, Andre Rusli \\ Department of Informatics, Universitas Multimedia Nusantara, Indonesia
}

\begin{tabular}{l} 
Article Info \\
\hline Article history: \\
Received Aug 10, 2019 \\
Revised Oct 14, 2019 \\
Accepted Dec 4, 2019 \\
\hline Keywords: \\
Augmented reality \\
Behavioral intention to use \\
Game-based learning \\
Indonesian history \\
User experience
\end{tabular}

Article Info

Article history:

Received Aug 10, 2019

Revised Oct 14, 2019

Keywords

Augmented reality

Game-based learning

User experience

\begin{abstract}
History has a vital function in shaping the personality of the nation, the quality of humans, and the people of a country. However, one factor that influences learning behavior that could be improved is the students' interest in learning. The use of game-based learning has been proven to be effective in making activities to be more fun to do. Moreover, augmented reality technology also shows enormous potential in the world of education. This research developed a game-based historical learning application using augmented reality to enhance user experience in learning history. The application is built using the Unity Game Engine and Vuforia. Furthermore, the application was tested and evaluated by measuring the perceived usefulness and perceived ease of use following the guidance in the Technology Acceptance Model. The result shows that the application achieves $89.5 \%$ for perceived usefulness and $86.33 \%$ for perceived ease of use.
\end{abstract}

This is an open access article under the CC BY-SA license.

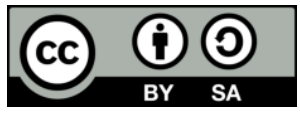

\section{Corresponding Author:}

Andre Rusli

Department of Informatics,

Universitas Multimedia Nusantara,

Kampus UMN, Scientia Garden, Jl. Boulevard Gading Serpong, Tangerang, Banten, Indonesia.

Email: andre.rusli@umn.ac.id

\section{INTRODUCTION}

History serves as a foundation of a nation to look into the future and grasp the vision of an independent nation. Learning and studying the history of Indonesia is not only about memorizing years and people's names but also understanding the value of a historical event. The role of history learning at its core is to deepen the understanding of the past and current events and interconnected relations with the future. History is a dialog between past events and its development to the future [1]. Furthermore, history also serves another vital function in shaping a nation's identity and human quality for generally every member of the society in Indonesia. However, there are still doubts about its role and importance regarding its success due to the teaching and learning methods employed by educators across the islands of Indonesia.

Several historians and experts on history education mentioned that one of the significant factors that could be improved is the learning model. One expert, Hamid Hasan, mentioned that the current problem in history education is that it is considered hard by the students to find the relevance between the learning materials and the current living conditions, placing the student as passive learning, resulting in the lack of motivation to learn [2]. Moreover, another critical factor is the will to learn. Slamento [3] identified the will to learn as an essential internal psychological factor that could affect the students in learning their nation's history. It is considered that strengthening the connection between the student's connection to the outside learning materials could lead to a more passionate learning experience. Game-based learning is known to be an effective method to make typically dull or less exciting work to be much more fun to do, leading to more time spent by the users to do something [4]. Its use in the educational sector could improve 
the learning experience, thus improving the students' will to learn more. The use of game components and user types also play a massive role in the method's success or failure [4]. Besides, augmented reality is also a topic that is gaining traction in the educational sector. It is a technology that could create a chain of visualization effects by placing virtual objects onto the user's physical environment [5]. Moreover, users can also interact with the augmented objects; thus when utilized in the educational sector, it could solve the problem of passive learners by providing means for the students to interact with the learning materials.

Game-based learning methodology has been successfully implemented on several works to improve the experience when studying math [6], English [7], and also including one which result shows that educational video games can indeed be an effective means of creating conditions for flow, heightened engagement (including interest, concentration, as well as enjoyment), and immersion [8]. On the other hand, several pieces of research [9-12] have also shown that augmented reality-based games hold high potentials to be used in the educational community. Especially its ability to enable its users to have new perspectives regarding their surroundings. Furthermore, the combination of both can also be found to be used in various researches, including one which successfully improving motivation and effectiveness in learning English vocabulary [13]. However, at least until this research was conducted, none could be found to support history education in Indonesia using both of the techniques. Various previous pieces of research have already addressed the use of augmented reality and e-learning technology to support the educational sector [14, 15]. Furthermore, in order to validate the metholodogies that are used in this research, several fundamental theories are reviewed, including game-based learning [16], game design [17], game elements (formal and dramatic elements) [18, 19], Unity [20, 21] Vuforia [22], Technology Acceptance Model [23- 25], and Likert scale [26]. This research aims to evaluate the usability of game-based learning and augmented reality to improve students' experience in learning, in this paper, specifically in learning the nation's history. The objective is achieved by developing an interactive game application by utilizing both techniques and then evaluating its user acceptance. The developed application is expected to be able to display the potential of game-based learning in the educational sector in Indonesia and to enable students all over our country to understand their nation's history and enjoying it in the process.

\section{RESEARCH METHOD}

This research's methodology is as follows: problem identification, literature review, system design, construction, testing, and evaluation. In our research, the problems, the need to improve the Indonesian history education learning model, and to improve students' motivation, are first identified and defined. Secondly, works of literature and related works are reviewed to find similar problems and methods to solve similar problems. Furthermore, after the literatures are reviewed, the application is then designed activities are done, defining the game structure, app flows, user interfaces, and creating the game assets. Table 1 below shows some game assets $(2 \mathrm{D}$ and $3 \mathrm{D})$ that were created for the application, while Figure 1 shows the overall flowchart describing how the game works, from when the app is started, when various menu items are clicked, until it is closed.

Table 1. Game assets (2D and 3D)

\begin{tabular}{ccc}
\hline Asset Name & Additional Information \\
3D model - Soekarno & Created by: Jonathan James Kapoyos (UMN) \\
Sprite dialog - Pattimura & Created by: Shintia Trista (UMN) \\
Background gameplay - Village & Source: villagerpost.com \\
Background gameplay - Old House Interior & Source: liputan6.com
\end{tabular}


As shown in Figure 1, when the user first opens the application, the Player's data will be loaded, and the main menu screen is displayed. Several menus can be navigated from there, such as AR Room, User Achievements, About App, Library, and the Enter Username screen. After all the needed design artifacts are created, the system is then built using Unity and Vuforia. After it is finished building, the user acceptance test and evaluation are done.

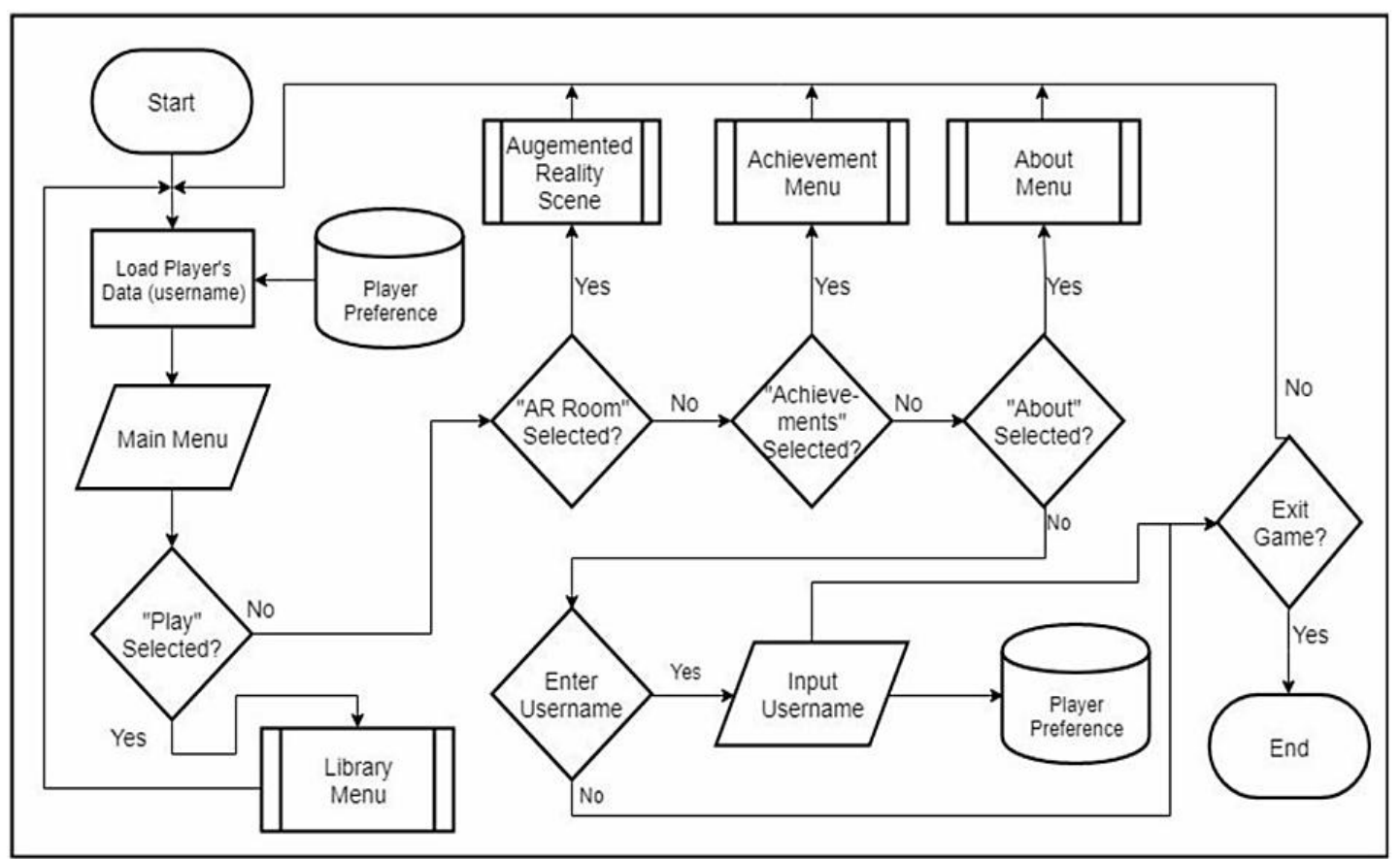

Figure 1. Overall historiAR game flowchart

\section{RESULTS AND DISCUSSION}

\subsection{HistoriAR}

The resulting game application is entitled HistoriAR. It is implemented by a game-based learning concept and utilizes augmented reality technology, built using the Unity game engine. The game application contains interactive stories about Indonesian history that engage the users to interact with the characters inside the application. Vuforia SDK supports the augmented reality technology. Figure 2 displays the AR marker that is used in the application to show assets in the augmented reality scene.

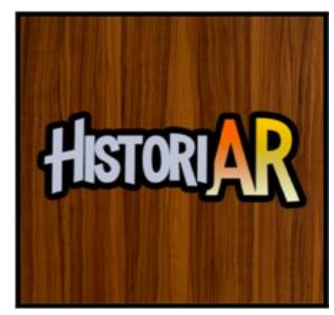

Figure 2. HistoriAR Marker

Figure 3 shows the main screen when the game is run. As the flowchart in figure 1 depicted, users can choose to start the game, view the Augmented Reality Room, check his/her achievements so far, or see information about the application. If the user chooses to start the game by pressing the Play button, the user will be directed to the next screen displayed in Figure 4, displaying the stories that are available for playing, for now, two main stories are depicting the history related to Bung Tomo and Pattimura. 


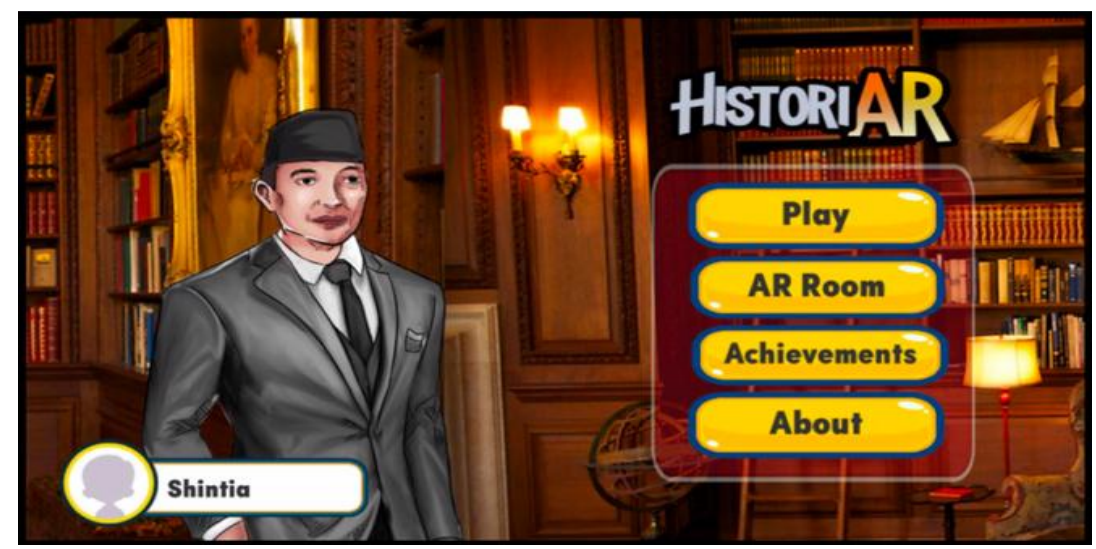

Figure 3. Main menu screen

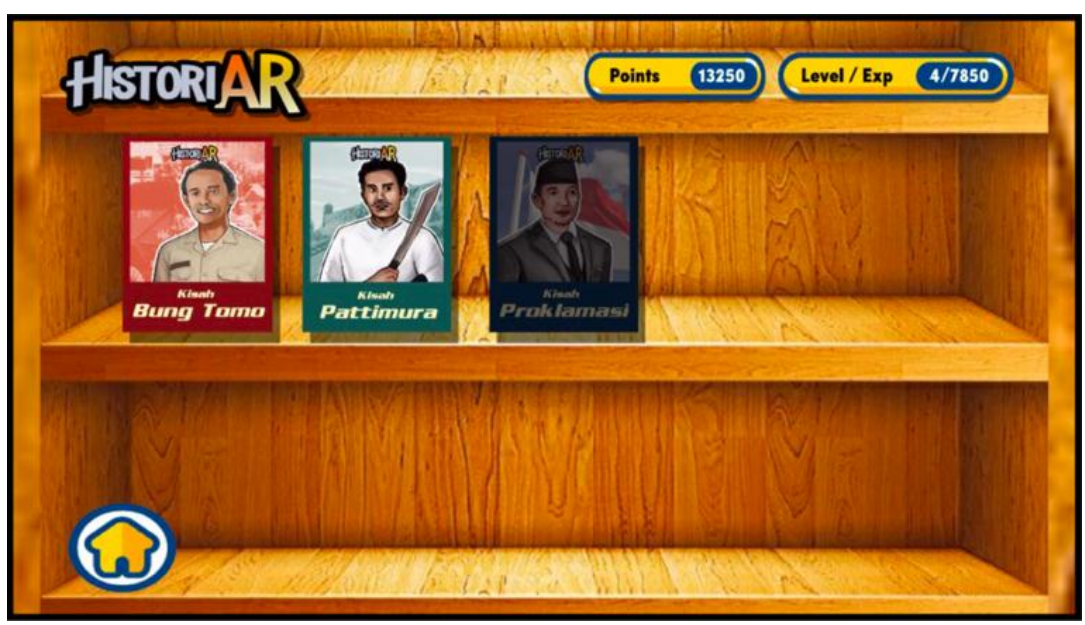

Figure 4. Game library

After the user selects a story he/she wants to play, the app will show the description and provide the PLAY button to start the game, as shown in Figure 5. Furthermore, Figure 6 shows the opening story that will continue as the user progresses through the game, learning history while interacting with the application.

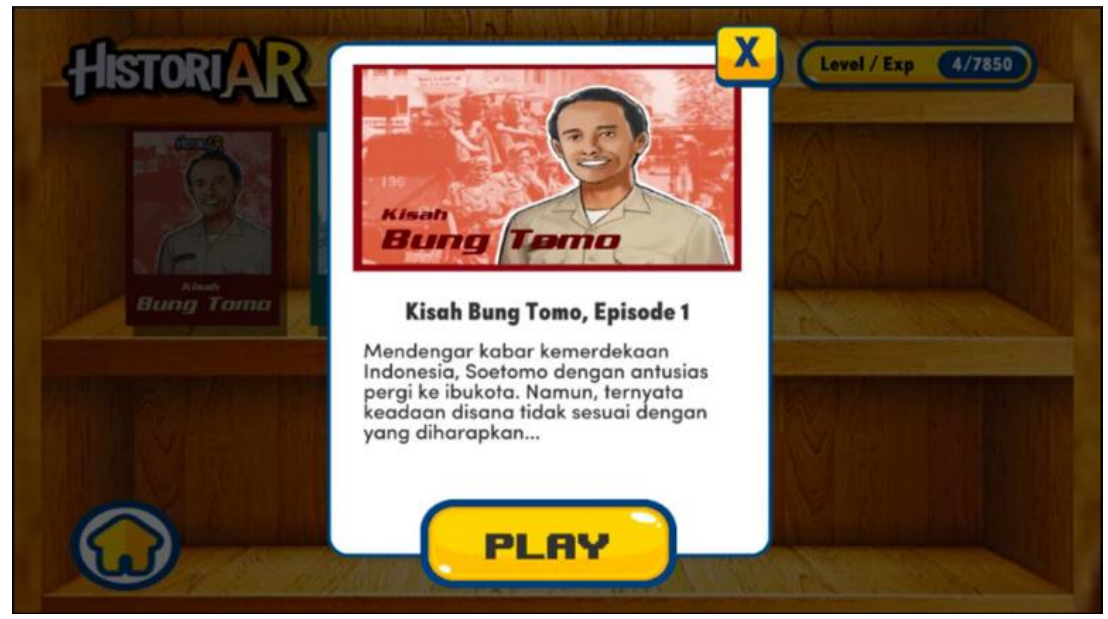

Figure 5. Story description 


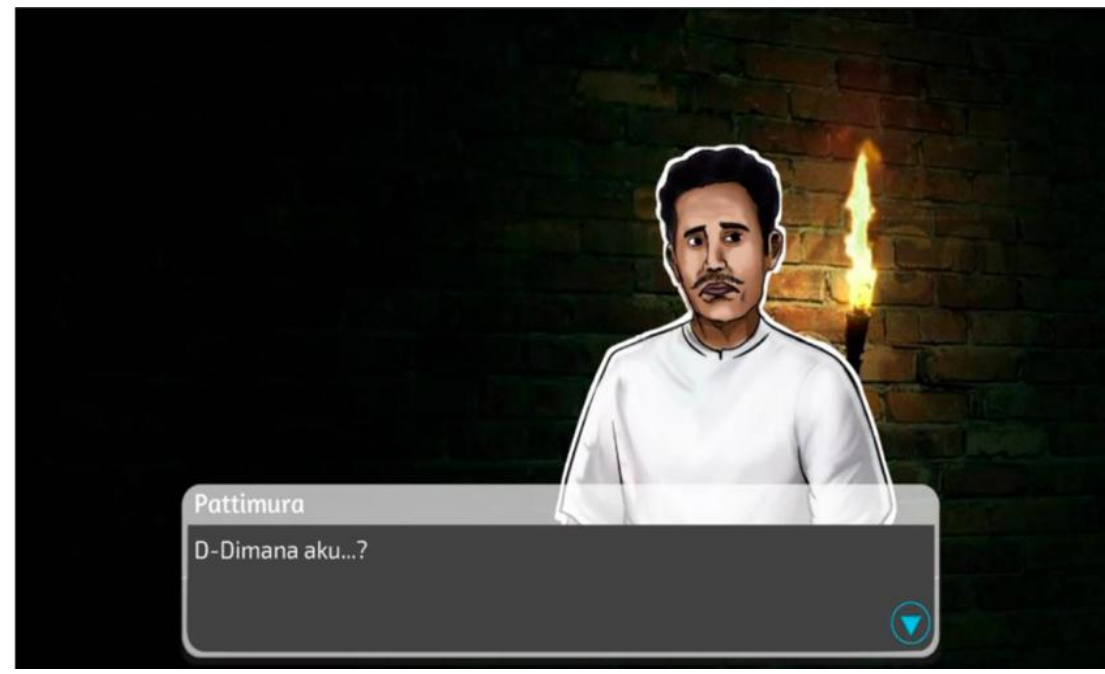

Figure 6. Sample game story on "Pattimura"

Figure 7 shows the AR Room mode, showing several historical figures in Indonesian history, such as Ir. Soekarno, Indonesia's first president. Users can control the camera angle and read descriptions regarding the characters while viewing their 3D figures in an augmented reality scene.

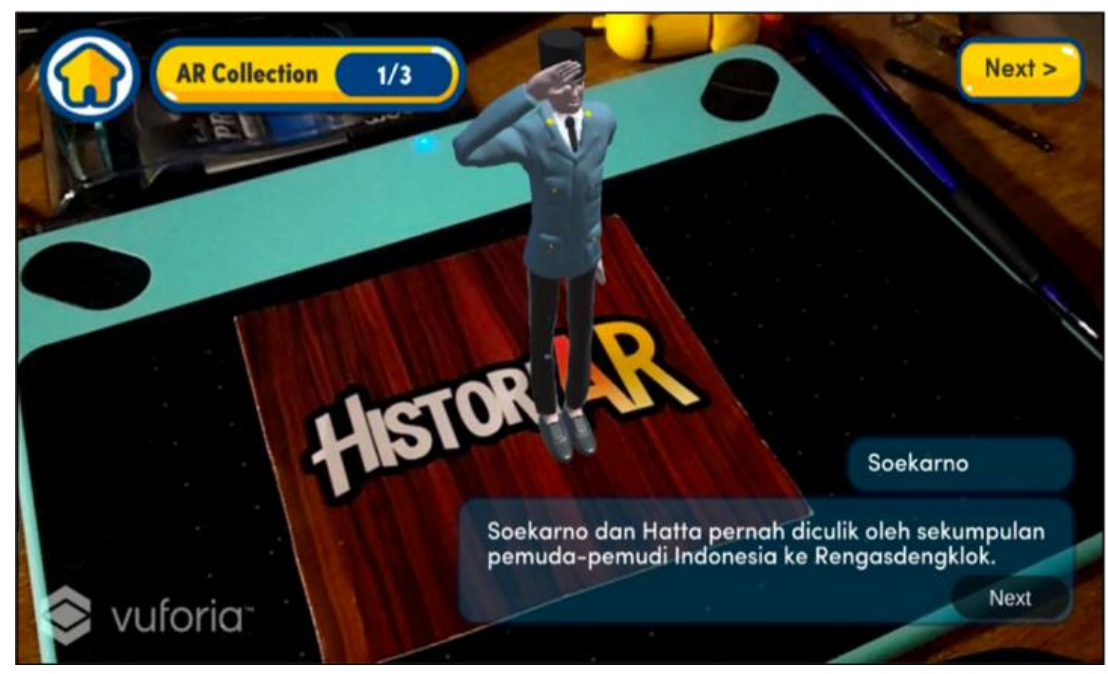

Figure 7. Augmented Reality Room Mode

\subsection{Testing and discussion}

After the game application has been finished built, software testing is conducted to evaluate the users' acceptance. Testing is done by gathering the respondents and started by explaining the application features; then users are asked to use the app. After the users finished using the application, questionnaires are distributed to evaluate the app's perceived usefulness and perceived ease of use, based on the theory in the Technology Acceptance Model. In our case, perceived usefulness means that the users think that the application is useful to help students in learning Indonesian history, while perceived ease of use means that the users think that the application is easy to use and understand, that users do not feel confused when using the application. Figure 8 represents the environment in which the test was conducted.

Based on the questionnaire results, respondents strongly agree that the application is perceived to be useful as the scores achieved $89.50 \%$ on that aspect. For the other aspect, respondents strongly agree that the application is perceived to be easy to use, shown by the score achieving $86.63 \%$. 


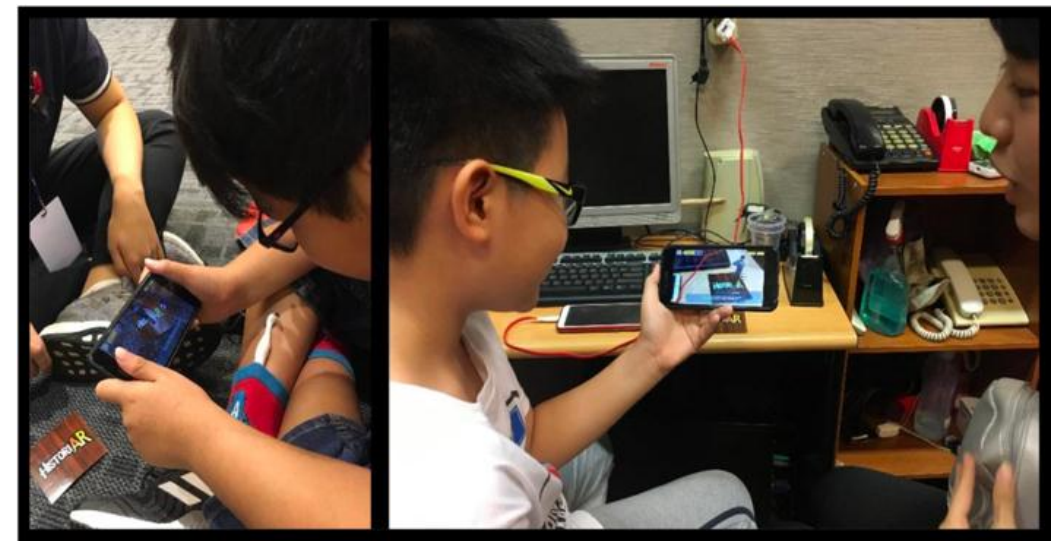

Figure 8. User acceptance test environment

\section{CONCLUSION}

This research has developed a game for studying Indonesian history by implementing the game-based learning method and augmented reality technology in the Android platform using Unity Game Engine and Vuforia SDK for Augmented Reality. The conducted user acceptance test proves that the application receives $89.5 \%$ score for perceived usefulness and $86.63 \%$ for perceived ease of use. These results further show the potential of using game-based learning and augmented reality to support and enhance learning experiences, including in educational institutions across the country. Future works could add more historical facts and contents for the students to learn, employ other methods and technologies to improve the learning experience. Moreover, the use of other metrics to measure user acceptance can be implemented, especially to measure user's immersion and joy, which are the universal aspects for a game application.

\section{REFERENCES}

[1] Kochar, S. K., "Pembelajaran Sejarah,” Jakarta Grasindo, 2008.

[2] Alfian, Magfalia, "Pendidikan Sejarah dan Permasalahan yang Dihadapi," Jurnal Ilmiah Kependidikan, vol. 3, 2011.

[3] Slamento, "Belajar dan Faktor-Faktor yang Mempengaruhinya," Jakarta: PT Rineka Cipta, 2003.

[4] Yusuf, Heni, "Penggunaan Gamifikasi dalam Proses Pembelajaran," Jurnal TICOM, vol. 5, no. 1, pp. 1-6, 2016.

[5] Azuma, Ronald T, "A Survey of Augmented Reality," Teleoperators and Virtual Environments, vol. 6, no. 4, pp. 355-385, 1997.

[6] R. Chang and C. Yang, "Developing a mobile app for game-based learning in middle school mathematics course," 2016 International Conference on Applied System Innovation (ICASI), Okinawa, pp. 1-2, 2016.

[7] S. Tao, Y. Huang and M. Tsai, "Applying the Flipped Classroom with Game-Based Learning in Elementary School Students' English Learning," 2016 International Conference on Educational Innovation through Technology (EITT), Tainan, pp. 59-63, 2016.

[8] Hamari, J, Shernoff, D J, Rowe, E, Coller, B, Asbell-Clarke, J, Edwards, T. "Challenging games help students learn: An empirical study on engagement, flow and immersion in game-based learning," Computers in Human Behavior, vol. 54, pp. 170-179, 2015.

[9] Klopfer, E., Sheldon, J, “Augmenting Your Own Reality: Student Authoring of Science-Based Augmented Reality Games," New Direction of Youth Development, pp. 83-94. 2010.

[10] Wei. X, Guo. D, Weng. D, "A Study of Preschool Instructional Design Based on Augmented Reality Games," Communications in Computer and Information Science, IGTA, vol. 875, 2018.

[11] Hwang G. J, Wu P. H, Chen C. C, Tu N. T, "Effects of An Augmented Reality-Based Educational Game on Students' Learning Achievements and Attitudes in Real-World Observations," Interactive Learning Environments, pp. 1-12, 2015.

[12] Majid, N. A. A., Mohamed, H., Sulaiman, R, "Students' Perception of Mobile Augmented Reality Applications in Learning Computer Organization," Procedia - Social and Behavioral Sciences vol. 176, pp. 111-116, 2015.

[13] Chen, S. Y., Hung, C. Y., Chang, Y. C., Lin, Y. S, Lai, Y. H, "A Study on Integrating Augmented Reality Technology and Game-Based Learning Model to Improve Motivation and Effectiveness of Learning English Vocabulary," 1st International Cognitive Cities Conference (IC3). Okinawa, pp. 24-27, 2018.

[14] Mustikaningrum, D., Retnowardhani, "A. Usability of BLESS-implemented class room: a case study of mixtio," Telecommunication, Computing, Electronics and Control TELKOMNIKA, vol.17, no. 2, pp. 703-711, 2019.

[15] Andrea, R, Lailiyah, S, Agus, F, Ramadiani. "Magic Boosed an elementary school geometry textbook with markerbased augmented reality," Telecommunication, Computing, Electronics and Control TELKOMNIKA, vol. 17, no. 3, pp. 1242-1249, 2019. 
[16] Prasetyo, Andri, “Game-based Learning and The Importance of Attractive Quests," 2014.

[17] Adams, E. \& Andrew Rollings, "Fundamentals of Game Design, Third Edition. New Jersey: Perason-Prentice Hall," 2007.

[18] Fullerton, T, "Game Design Workshop - A playcentric approach to crating innovative games - 2nd edition," Southern California, United States. 2008

[19] Gibson, J, "Introduction to Game Design, Prototyping and Development: From Concept to Playable Game with Unity and C\# 1st Edition," Michigan, United States, 2014.

[20] Zomacj, I, "Introduction to Unity," http://code.tutsplus.com/tutorials/introduction-to-unity3d-mobile-10752, Accessed on 22 November 2018.

[21] Unity, "Unity's interface," https://docs.unity3d.com/Manual/UsingTheEditor.html, Accessed on 7 October 2018.

[22] Vuforia, "Vuforia Developer Library Overview," https://library.vuforia.com/content/vuforia-library/en/gettingstarted/overview.html, Accessed on 14 Oktober 2018.

[23] Kenneth, Younghwa, et al., "The Technology Acceptance Model: Past, Present and Future," Communication of The Association for Information System, pp. 752-780, 2003.

[24] Davis, D. F., Perceived Usefulness, "Perceived Ease of Use, and User Acceptance of Information Technology," Management Information Systems Quarterly, vol. 13, no. 3, pp. 319- 340, 1989.

[25] Arvie, D., Tanaamah, A. R, "Technology acceptance model for evaluating IT of online based transportation acceptance: a case of GO-JEK in Salatiga," Telecommunication, Computing, Electronics and Control TELKOMNIKA, vol.17, no. 2, pp. 667-675, 2019.

[26] Budiaji, W, "Skala Pengukuran dan Jumlah Respon Skala Likert," Jurnal Ilmu Pertanian dan Perikanan, vol. 2, no. 2, pp. 127-133, 2013.

\section{BIOGRAPHIES OF AUTHORS}

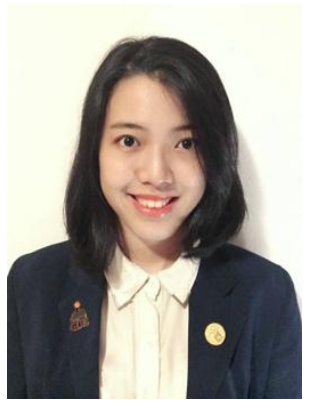

Shintia Trista was born in Jakarta, Indonesia, in 1995. She received the bachelor's degree in Informatics from Universitas Multimedia Nusantara, in 2019. Her research interests include a user and learning based game programming design systems. She also holds interests in digital drawing for game design and art and as a game artist.

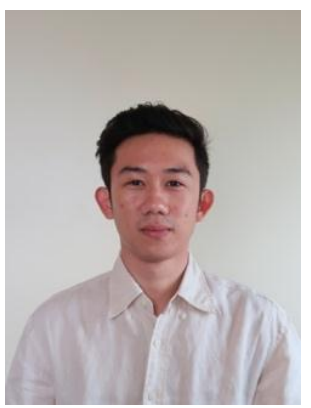

Andre Rusli received his Master's of Science degree in Information Environment from Tokyo Denki University, Japan, in 2017, focusing in the Software Requirements Engineering field. He is currently a lecturer and researcher in Universitas Multimedia Nusantara and also serving as the head coordinator of the Mobile Development Laboratory. His research interests include requirements engineering in software application development, natural language processing, and human computer interaction. 